Mid-American Review of Sociology Ritzer, George. 1975a. Sociology: A Multiple Paradigm Science. Boston: Allyn
and Bacon.

1975b. "Professionalization, Bureaucratization and Rationalization:

The Views of Max Weber." Social Forces June:627-634.

1981. Toward an Integrated Sociological Paradigm: The Search for an 1983 "The Image of the Subject Matter. Boston: Allyn and Bacon.

6:100-107.

Delineation "Sociological Metatheory: A Defense of a Subfield by a 1990a. "The Parameters." Sociological Theory 6:187-200.

Syntheses." Pp 1-30 in Frontiers of Sociological Theory: The New

edited by George Ritzer. NY: Cof Social Theory: The New Syntheses, 19906 Mrge Ritzer. NY: Columbia University Press.

Metatheoretical Tool." Pp. 347-370 in Frontiors of Sheory: Applying a

Syntheses, edited by Geors 1991a. Metatheorizing in Ritzer. NY: Columbia University Press.

1991b. "Biography: A in Sociology. Lexington, MA: Lexington Books. Contemporary Sociology 20:10-12.

- Forthcoming a. "Agency-Structure and Micro-Macro Linkages: Agency, edited by Bjorn Wittrock Agency, edited by Bjorn Wittrock.

. Forthcoming b. The McDonaldization of Society. Lexington, MA:

Ritzer, George (ed.). 1972. Issues, Debates and Controversies: An Introduction to Sociology. Boston: Allyn and Bacon.

1990a. Frontiers of Sociology: The New Syntheses. New York: Columbia University Press.

Ritzer, George and Harrison Trice, 1969. An Occupation in Conftict $A$ Sudy of the Personnel Manager. Ithaca, NY. Coccupation in Conflict: A Study

Ritzer, George and David Waltaca, NY: Cornell University. edition. Englewood Cliffs NJ. Prenti Working: Conflict and Change. 3rd ion. Englewood Cliffs, NJ: Prentice-Hall.

. 1988. "Rationalization and the Deprofessionalization of Physicians." Social Forces 67:1-22.

Sica, Alan. 1991. Review of Bennett Berger, ed Authors of Their Own Lives. Science January 18, 1991, 251, 4991:324.

\section{META-SOCIOLOGY: DOINGS AND REFLECTIONS}

\author{
W. Richard Scott
}

Stanford University

Mid-American Review of Sociology, 1991, Vol XV, No. 2:33-42

It's a pleasure to be here. In listening to the previous speakers, it's clear that $\mathrm{KU}$ is a special place that evokes fond memories from those of us who have had any connection with her. I am delighted to be a part of this celebration; and I am honored to be among those whom you have asked to return and to participate.

I have called my remarks "Meta-Sociology: Doings and Reflections." Like many of you, I am not quite sure what "meta" means, but, knowing that George Ritzer was going to address a related theme, I was depending on him to give you the in-depth interpretation. I will settle for the shallow view. I think I got my first sense of this concept from watching the Gary Shandling Show. You recall how Gary often goes off the TV set and watches the other characters on the TV monitor to find out what they are saying and in the scenes in which he is not involved. To make a "meta" approach is to step out of doing the usual kinds of things we do--the teaching, the research, the advising--and, instead, to reflect on what we are doing: to attempt to make sense of what we are up to when we teach, inquire, advise, and so on. So I am here not to talk about my research but about why I decided to do the research that I did; I am here not to present my work but to talk about what working means to me; I am here not to do sociology, but to talk about doing sociology.

Before I begin to engage in such talk, three quick comments on this type of enterprise. First, the exercise is enticing. There is something fascinating about self-reflection. I think we are all intrigued by biographies--especially our own. When Alan Sica invited me to talk about the development of my own career, my first reaction was disbelief; my second, anxiety; and my third, attraction. I began to feel more and more like Gilbert and Sullivan's elderly Duchess, "who doesn't think she dances, but would rather like to try."

Second, I must point out that the exercise, if performed en masse, could be harmful to the field. The danger is well described in Carl Sandburg's poem, "The People, Yes," in which everyone agreed on a given signal to shout so as to be heard by the heavens; but when the moment came, there was complete silence because everyone wanted to hear the wonderful noise. In short, if we all become too self-reflective, there will be no one to do the work.

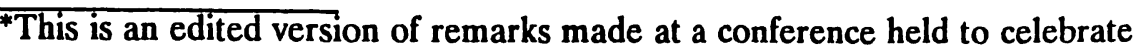
the centennial of the founding of the Department of Sociology at the University of Kansas, Lawrence, Kansas, on April 5-6, 1991. 
Third, however, self-reflection is surely a good thing. It is instructive-and it certainly has been enjoyable for me at this event--about the life journey of one's colleague's; to hear about some of the choices that they confronted and the decisions they made. I think we social scientists do not do enough of this. I am pleased to see that some of our illustrious colleagues have written full-fledged biographies--a recent example is George Homans (1984). There are in addition recent collections of essays by sociologists such as those edited by Bernard Barber (1990) and Matilda Riley (1988), who have been asked to write about their work and how it relates to their circumstances and times. And some of you may know that we inaugurated a few years ago a series of prefacatory chapters, one in each volume of the Annual Review of Sociology, by leading scholars in our discipline who were invited to reflect on some aspect of their life's work. It is good to begin to compile this kind of record about the history and development of our field.

My comments today will be in two parts. I will attempt first to provide a brief portrait of where I came from and where I am now, in short, my "Doings." I will give particular attention to the Kansas years. Second, I will briefly "Reflect" on that development, examining some of the general axes around which my career has been constructed.

\section{DOINGS}

In discussing my development, I thought I would follow the example of Offenbach's Hoffman and tell the Tale of "My three great loves." They are (to the relief of my wife) three Universities: Kansas, Chicago, and Stanford.

A brief note on my early beginnings. I was born and raised in Parsons, Kansas--which is, as most of you surely know, "Queen city of Southeast Kansas." I entered on the scene in the early days of the great depression, but was lucky. My father held a good, steady civil service job in the U.S. Post Office, with the result that my family and I enjoyed a stable and secure lifestyle. I was born at home and lived in that same house until I left Parsons for Lawrence to complete my undergraduate degree. I think I was much more influenced by my mother than by my father. She had a better than average education for her time, having taken some college work at the neighboring town of Pittsburg (then Pittsburg Teacher's College). She was what I would term a "community-building woman:" active in a wide array of community service organizations ranging from church missionary support groups and the PTA to the Red Cross. She believed strongly that one should try to make a difference; and I acquired from her a strong sense of the importance of public service.

I think that it is significant, in thinking back on that early time, that two of my favorite maiden aunts and some of my earliest and my closest friends were teachers. My life was centered at school and, to a lesser extent, at church. I was involved in drama groups, debating teams, choirs, play-reading groups, journalism activities, and the Hi-Y. For financial reasons, I remained in Parsons through the completion of junior college. Although I considered going to a small Presbyterian college in Emporia (where, unbeknownst to me my future wife was enrolled), I decided to complete my undergraduate degree at $\mathrm{KU}$.

How can I make you understand what the first few days and weeks in Lawrence meant to me? It was my first time living apart from my family; it was my first museum; my first art gallery. It was my first exposure to live classical music. (I remember attending my first concert in the little auditorium in Strong Hall, hearing Rienhold Schmidt perform Mahler's "Kindertotenlieder" with a small chamber orchestra, and thinking I must have died and gone to heaven!) It was my first pizza--or as we called it in those days, "pizza pie." It was my first attendance at a formal evening lecture series. I walked around the halls and corridors at $\mathrm{KU}$, and I would see signs advertising this or that lecture or concert and I assumed that students should go to all of them; and, for a while, I did. I felt like a kid turned loose in a candy store

On arriving at $\mathrm{KU}, \mathrm{I}$ declared a philosophy major. At the time, I had a vague idea that I was going to become a minister. (Unlike Erik Wright, I had at this point no sense of what a college professor was or did.) It has come to my attention that a large number of my sociological colleagues have considered the ministry or have parents who were ministers; and I remind you that Robert E. Park once remarked that "If you scratch a sociologist, you will find a reformer." While it is not true for all, it is for many that sociology is where the committed go when they have lost their faith but not their hope. I had serious doubts about a religious vocation, but a strong interest in trying to do something that might make a difference for the better.

I now call attention to one other important first for me at KU: my first sociology class. In my first semester here, I took Elements of Sociology from Marston McCluggage, and I knew instantly that I had found my calling. Not only was sociology raising the right questions--unlike philosophy, it provided some methods for seeking and selecting among answers. No one would accuse Marston of being a spell-binding lecturer, but, nonetheless, with his help, I fell under the spell of sociology. I also point out that I was not recruited by the false promise of luxury and comfort. At the time when I became a sociology major, the department was housed in an aging set of "temporary" barracks, left over from the post-war era, hidden from public view behind Strong Hall. The facilities were shabby but that did not seem to impair the morale of the faculty or stifle the life of the mind.

I took additional courses in my senior year with Carroll Clark, Jack Baur, and Gordon Erikson. But I believe the faculty who most influenced my development at this time were Charles Warriner and Ted Nelson. Nelson was not a member of the sociology department, but taught in the program of Human Relations. He had been trained in and had adapted the Harvard case methods teaching approach; most of the cases focused on human relations in industry. There was a useful tension between this emphasis, which was to focus on the facts and the specifics of a situation on the one hand, and the approach emphasized by Warriner in his course on social organization, which was to think abstractly and to attempt to generalize across situations. While 
this created some interpersonal tensions and internal conflicts for me at the time, I think that these are tensions that are built into the sociological approach, and it was good for me to encounter and wrestle with these issues at an early stage.

At the end of my senior year, Carroll Clark and Walter Sandelius, a thought-provoking Professor in the Department of Political Science, nominated me for a Woodrow Wilson Fellowship, which I was fortunate to receive. This Fellowship entitled me to a year's support of graduate study at any University of my choice. Since I had come to $\mathrm{KU}$ as a junior-college transfer student, I unly had the opportunity to work a little over a year with members of the KU faculty. Recognizing how much I could still learn from them, I decided to stay on at KU for the completion of my MA degree. (I was perhaps slightly influenced by the fact that my then girlfriend--now wife--was living nearby.)

During my first year of graduate study, I worked as a research assistant with Chuck Warriner. It was with him that I got my first serious introduction to organization theory; and it was as his RA that I carried out my first empirical research project. We together studied the social organization of a small hospital in Kansas City. And it was in connection with this project that I conducted my thesis research: a study of the socialization process of student nurses.

My own socialization that year was greatly affected by my living situation. I had moved out of the scholarship hall I occupied as an undergraduate and into the Hill Coop, a small self-governing community of 14 graduate students who lived together in what was either a large garage or a small carriage house behind one of the fraternities. The Hill Coop provided a marvelous supplement to my graduate education, and added another series of "firsts" to my growing set of experiences: my first close relation with a foreign student (my roommate was Pakistani); my first homemade suki-yaki; my first celebration of Rosa Luxemburg's birthday; and similar memorable ocrasions.

When the time cane for me to decide where to pursue doctoral studies (I don't recall that there was any questions of whether, only of where), I polled the KU faculty and was surprised at the amount of consensus: most agreed that if I were admitted, I should go to the University of Chicago. I did not realize until later the basis for this consensus: virtually all of the $\mathrm{KU}$ faculty had been trained at Chicago, a school that dominated sociology in middle America the first half of this century.

So on, more briefly, to my second love: Chicago. I have heard others describe their graduate experience at Chicago as "like trying to drink from a fire hose!". While there is no doubt that this University is an intellectual powerhouse, at the time I arrived in Chicago with my new bride in the mid 1950s, the water pressure was low in the Department of Sociology. Ernest Burgess, Lloyd Warner, Louie Wirth were either gone or semi-retired, a number of younger social psychologists had not been given tenure, and only the demographers and ecologists were at full strength. Under these cir- cumstances, I adapted to the environment and worked closely during my first two years with the ecologist, Otis Dudley Duncan.

There is a reason why the symbol of the University of Chicago is a Phoenix: the Department of Sociology at this institution has a remarkable capacity to rise from the ashes after a period of decline and return to strength. Shortly after I came to Chicago and found less intellectual housepower than I had hoped, the Department hired, in quick succession, James Coleman, Peter Rossi, Peter Blau, and Elihu Katz. Suddenly, the place was vigorously alive again, humming with energy and ideas.

I will spare you the details of my four wonderful Chicago years, and instead make only two comments on that time. First, in terms of opening horizons, I think it is fair to say that for me Chicago was to Lawrence as Lawrence was to Parsons: my world continued to expand and to become more complex and interesting. Second, I was confronted with the difficult choice of continuing to work with Duncan, who I much admired, on studies of metropolitan hierarchies (sce Duncan, Scott, Lieberson, Duncan, and Winsborough 1960) or to shift iry field of study to organizations and work with Peter Blau. I chose the latter alternative and have never regretted the decision. But I feel extremely fortunate that during my time at Chicago I was able to work closely with two of the great sociologists of our time: Otis Dudley Duncan and Peter M. Blau.

With Blau's support, I received a Social Science Research Council Fellowship to support my dissertation research. More important, he asked me to co-author with him a treatise on organizations, utilizing data from one of his projects and my dissertation--a book that belped to launch my career in organizations (Blau and Scott 1962).

At the end of my Ph.D. work, I received an attractive offer from a private university on the West Coast. My wife and I had to get out our atlas to find out exactly where Stanford University was. We succeeded in locating it and agreed to go.

Stanford is and remains my third great love. I arrived there as the youngest member of a set of Young Turks who had arrived together with a mandate to reorganize the Department. Sandy Dornbusch was our leader, and as one five new faculty members, ${ }^{1}$ we spent an enormous amount of time in seminars and long, noisy lunches, arguing about the nature of science, the role of theory, the use of evidence, preparing to remake sociology.

I was a bit on the fringe of this stimulating group in several respects. First, my initial appointment at Stanford was half in sociology and half in the School of Medicine, this experiment being supported by the Russell Sage Foundation in its effort to connect sociology more effectively with the professional school. This program was directed at Stanford by Edmund Volkart, yet another mentor who provided support and friendship. Second, my sociology colleagues were primarily social psychologists and, as the token macro person, I was beginning to seek a broader colleague group to support my intellectual interests. Third, my sociology colleagues were, more so than I, committed to the value of formalization in theory development and to experimental studies 
as the premier methodology. I was, I think, more tolerant of diverse methods and styles of research, and more pragmatic in my judgments as to what types of work would advance progress in our discipline. With the ending of the Russell Sage Program, I moved full-time into the Department of Sociology but continued to cultivate colleagues and intellectual stimulation in other parts of the University, most notably, with James March in the School of Education and Harold Leavitt in the Graduate School of Business.

Virtually all of my scholarly work has been closely connected to the study of organizations. To my mind, organizations are among the most significant aspects of modern social structure, both as contexts within which individuals choose and act and as collective actors in their own right. During my years as a student of organizations, I have observed and, hopefully, contributed to a major reorientation of the field. In the late 196Us and early 1970s, organizational studies had become sociologically arid: the field was in danger of becoming little more than "management science:" a body of work that embraced the assumptions and agenda of those who were in charge of the systems under study. But forces too varied to enumerate here have allowed us to avert this unhappy prospect. Work carried out during the later 1970s and 80 s has reconnected organizational research with the enduring sociological issues: asking how organizations affect social inequality, the distribution of power; the definition of cultural symbols and of meaning.

As I look back over the body of work I have produced at Stanford, it appears to fall into four clusters of research interests, all of which I continue to pursue:

-Beginning with my MA thesis at $\mathrm{KU}$, continuing with my dissertation research with Blau, and still an important focus of my current research is the relation between professionals and bureaucracies. I increasingly see this relation as involving a conflict not simply between two kinds of workers but between two conceptions of how to organize work: two competing principles for the rationalization of complex work activities.

-Beginning with collaborate research with my department colleagues at Stanford, I have a long-standing interest in the nature of authority and the complex ways in which authority transforms power relations. This work began in collaboration with Sandy Dornbusch (Dornbusch and Scott 1975) but continues up to the present time in my work with John Meyer on the determinants of legitimacy of organizational systems (Meyer and Scott 1983).

-In collaboration with Ann Flood and others in sociology and with a number of colleagues in the Medical School at Stanford, I examined issues of effectiveness in professional organizations, especially hospitals (Flood and Scott 1987). I continue to have an interest in effectiveness, but my focus of attention has shifted from seeking to determine why some types of actors and systems are more effective than others to asking how and why the criteria by which effectiveness is judged vary from one system to another.

-For the last several years, I have been working, together with my colleague John Meyer, to develop a clearer conception of the institutional environments of organizations and to explicate the many ways they shape and influence organizational structure and activities. These interests have been pursued empirically in studies of mental health systems, medical care organizations, private and public school systems, and in examining the development of due process mechanisms and employee training programs in corporate firms and public agencies.

Note that, throughout, my work has been collaborative. I seem to think better, and I know I have a better time, when I am pursuing ideas in the company of others.

My faculty position at Stanford University was my first and has been my only job. I have been able to change my research interests and context without moving between institutions. Truman Capote has observed that one loses two IQ points for every year spent in California. If this is the case, I am in serious trouble, since I have resided and worked in California for over thirty years. And I like to think I still have some good years left.

\section{REFLECTIONS}

I turn, finally, to comment briefly on four axes or dimensions that have framed my choices of subject matter and style of work. The term "choice" is probably too strong, suggesting as it does conscious selection among known alternatives. Rather, I think it is more accurate to describe the process as one reflecting "inclinations:" preferences whose meanings and implications only become clear in retrospect.

Let me begin by mentioning a possible dimension along which choices are often framed, but only to reject it. I refer to the choice between "theory" and "research," which I regard as a false distinction, one I refuse to legitimate. I think the great power of sociology lies in testing arguments with observations; what Whitehead colorfully describes as confronting generalizations with "irreducible and stubborn facts" (Whitehead 1925). I believe in a division of labor, but not one that separates theory from research.

Now I turn to the four dimensions which I will employ. First, there is the hoary distinction between "basic" and "applied" research or, as I prefer to formulate it, between theory-driven and problem-centered research. I think that this distinction is overdrawn, particularly in areas such as sociology, but it is not without meaning. Some of us are more interested in solving social problems or in accounting for as much variance as possible in some social phenomenon. Such investigators place primary emphasis on the dependent variables: on that which is to be explained. Others among us, of whom I am one, are more interested in elaborating and testing theoretical arguments. We labor over the development of a theoretical framework and select our problems and situations because they can shed light on and test the scope of our arguments. We care more about the independent variables. I am currently, for example, conducting studies of corporate training programs, not because I want to improve them or explain all of their numerous features but because these programs can be used as an instance of the institutionalization of adult 
education and can thus help me better understand the ways in which such institutional environments shape organizational arrangements.

A second dimension, much discussed of late, is that between a micro and macro orientation. My own work has been relentlessly macro. In this prejudice, I no doubt reflect the influence of my mentors, Chuck Warriner, Dudley Duncan, and Peter Blau. My preference is to focus on social structures as the dependent variable: as the phenomenon to be explained; and my ontological assumption is that social structures are neither the aggregate tracings of individual behaviors nor the functionalist frameworks constructed by rational actors to solve the prisoner's dilemma or to avert the tragedy of the commons. I applaud current efforts to better link micro and macro approaches, but not reductionist attempts to dissolve macro structures into micro processes.

A third dimension reflecting contemporary choices of work styles has been labeled by Donald Kagan as separating "lumpers" from "splitters." Lumpers are persons with a preference for order. They like to look for the larger patterns; they focus on the big picture. While recognizing diversity and exceptions, they nonetheless seek to construct categories that exhibit uniformity within and reveal distinctions between. By contrast, splitters focus on the exceptions. They see as much diversity within as between categories, and emphasize the variety and cacophony of human efforts.

I am a confirmed lumper. I prefer order to disorder; and I believe that while there is much diversity, the diversity is itself patterned. I spend a lot of my time and energy synthesizing and ordering the work of others. I like to create comprehensive frameworks, not necessarily to reconcile the differences, but to show how they relate to each other: to discover the dimensions along which they vary so that we can better understand why and how they are different. It seems to me important that we identify and preserve that which is cumulative in our collective efforts; that we continually attempt to make sense of the differences revealed in our work.

I think this inclination is visible in much of my work: in a little-known textbook on sociology that tried to order the field in terms of a few generic processes and four levels of analysis (Scott 1970); in my better-known text on organizations that orders contemporary theories by cross classifying them as either rational or natural, open or closed (Scott 1987); and in my several contributions to handbooks and related synthetic efforts. It is no doubt the reason why I have been willing to spend a good many years on the editorial board of the Annual Review of Sociology and to serve as the editor of this publication for the last five years.

A fourth and final dimension distinguishes independent from interdependent work. I have already noted that virtually all of my own research has been carried on in collaboration with others. I strongly believe that scholarly work-in particular, scientific work--benefits from being collaborative.

I also believe in the value of interdisciplinary work, but only when it is grounded in strong disciplinary bases. The study of organizations benefits from the fact that economists, psychologists, sociologists, and others are not only looking at the same phenomenon but attempting to account for it in different ways. When we talk together about and attempt to sort out these differences, we learn more about the object of study.

The clearest evidence regarding the value I place on collaborative work is my career-long effort to build a community of researchers engaged in multidisciplinary research on organizations. Beginning with informal meetings with Jim March and Hal Leavitt in the early 1970s, we at Stanford have worked for more than twenty years to build such a network at Stanford. Our efforts were formalized in 1988 when the Stanford Center for Organizations was established--an enterprise incorporating more than eighty faculty affiliates. We also are well along in efforts to create a framework to support inter-university research and research training on organizations. A consortium of organizations research centers located at seven universities was established in 1990.

\section{CONCLUDING REMARKS}

In looking back over the days and years of my sociological career, it has been for me a stimulating and gratifying life. I am more than ever convinced of the value of a "a sociological persuasion:" a perspective that simultaneously emphasizes the constraints--but also the empowerment--of social structures; and one that examines how human action continually reproduces, but also renews and alters these structures. The effort to comprehend--to really understand the intricacies of these processes--will provide enough challenges and enough mystery to keep all of us motivated and occupied for a long time to come.

\section{ENDNOTES}

1. In addition to Sanford M. Dornbusch, this group included Joseph Berger Santo F. Camilleri, Bernard P. Cohen, and Morris Zelditch, Jr.

\section{REFERENCES}

Barber, Bernard, ed. 1990. Authors of Their Own Lives: Intellectual Autobiographies by Twenty American Sociologists. Berkeley: University of California Press.

Blau, Peter M. and W. Richard Scott. 1962. Formal Organizations: $A$ Comparative Approach. San Francisco: Chandler.

Dornbusch, Sanford M. and W. Richard Scott. 1975. Evaluation and the Exercise of Authority. San Francisco: Jossey-Bass.

Duncan, Otis Dudley, W. Richard Scott, Stanley Lieberson, Beverly Davis Duncan, and Hal H. Winsborough. 1960. Metropolis and Region. Baltimore: Johns Hopkins Press.

Flood, Ann Barry and W. Richard Scott. 1987. Hospital Structure and Performance. Baltimore: Johns Hopkins Press. 
Mid-American Review of Sociology

Homans, George. 1984. Coming to My Senses: The Autobiography of a Sociologist. New Brunswick, NJ: Transaction.

Meyer, John W. and W. Richard Scott. 1983. Organizational Environments: Ritual and Rationality. Beverly Hills, CA: Sage.

Riley, Matilda W., ed. 1988. Sociological Lives. Newbury Park, CA: Sage.

Scott, W. Richard. 1970. Social Processes and Social Structures. New York: Holt, Rinehart, and Winston.

. 1987. Organizations: Rational, Natural, and Open Systems. 2nd ed. Englewood Cliffs, NJ: Prentice-Hall.

Whitehead, Alfred North. 1925. Science and the Modern World. New York: MacMillan.

\section{A ROAD WORTH TAKING: SOCIOLOGY AS A VOCATION AND THE LEGACY OF CARROLL D. CLARK*}

Gary Foulke

University of Kansas

Mid-American Review of Sociology, 1991, Vol. XV, No. 2:43-57

The meaning of sociology as a vocation, as seen through the career of Carroll D. Clark, is the focus of this paper. As the chairperson of the Department of Sociology at the University of Kansas for over three decades, Clark had an extraordinary influence on the shape of the department at Kansas and the discipline in the Midwest. Through an examination of his career at Kansas, it is shown that sociology for Clark was indeed a calling a calling to which he devoted passionate enthusiasm and unwavering commitment. Also explored is Clark's role as a public intellectual.

As the discipline of sociology moves into its second century in the United States it is appropriate, indeed incumbent upon present-day sociologists to take stock of where we have been. While the discipline has grown and changed in myriad ways, the questions that each sociologist must face have in certain respects remained the same. The question that this paper will attempt to deal with is the question of sociology as a vocation. How has the meaning of the vocation changed for sociologists over time?

In attempting to answer this question, it is fruitful to look at the lives and careers of sociologists to see how the idea of vocation is reflected in their work. The opportunity to ascertain what sociology has meant to others in the past can help give perspective to the role of the sociologist today. In 101 years at the University of Kansas, the department of sociology has seen the tenure of many outstanding faculty, including Ernest Burgess, Loren Eiseley and Seba Eldridge. Yet Carroll Clark is one individual who consistently stands out in the history of the Kansas department.

*Discussions with E. Jackson Baur, Charles Warriner and Norman Yetman provided significant insights for this paper, for which I thank them. I also thank David Norman Smith and Laura Z. Barter for their helpful comments, and the staff at the University Archives, University of Kansas, for their assistance in preparing this paper. 